\title{
Surfaces
}

\section{Studying English Literature in the Transnational University}

\section{J. Hillis Miller}

Volume 6, 1996

LES ÉCONOMIES DISCURSIVES DU SAVOIR ET DE LA CULTURE DANS LE SILLAGE DE L'OEUVRE DE BILL READINGS

THE DISCURSIVE ECONOMIES OF KNOWLEDGE AND CULTURE, WITH CONSTANT REFERENCE TO THE WORK OF BILL READINGS

URI : https://id.erudit.org/iderudit/1064849ar

DOI : https://doi.org/10.7202/1064849ar

Aller au sommaire du numéro

Éditeur(s)

Les Presses de l’Université de Montréal

ISSN

1188-2492 (imprimé)

1200-5320 (numérique)

Découvrir la revue

Citer cet article

Miller, J. H. (1996). Studying English Literature in the Transnational University. Surfaces, 6. https://doi.org/10.7202/1064849ar
Résumé de l'article

En prenant comme point de départ la fin de la guerre froide, le déclin le l'État-Nation, la mondialisation de l'économie et de la recherche, les transformations radicales apportées par les nouvelles technologies de la communication, et enfin les changement effectués par les gouvernements afin de trouver des ressources pour les corporations transnationales, cet essai examine le rôle des études littéraires et des sciences humaines dans le contexte des universités transnationales qui sont en train d'émerger...
Copyright $@$ J J. Hillis Miller et Stanford University Press, 1996

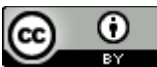

Ce document est protégé par la loi sur le droit d'auteur. L'utilisation des services d’Érudit (y compris la reproduction) est assujettie à sa politique d'utilisation que vous pouvez consulter en ligne.

https://apropos.erudit.org/fr/usagers/politique-dutilisation/ 


\title{
Studying English Literature in the Transnational University
}

\author{
J.Hillis Miller \\ Department of English and Comparative Literature \\ University of California, Irvine, CA 92717 \\ jhmiller@uci.edu
}

Surfaces Vol. VI. 204 (v. 1.0A - 01/12/1996) - ISSN: 1188-2492

Copyright (c) Stanford University Press

Copyright for texts published in Surfaces remains the property of authors. However, any further publication should be accompanied by an acknowledgement of Surfaces as the place of initial publication.

\begin{abstract}
Against the backdrop of the end of the Cold War, the decline of the Nation-State, the globalization of economies and research efforts, the radical transformations being brought about by new communications technologies, and the shift in funding from government sources to transnational corporations, this essay examines the role of literary studies and the humanities in the context of the emerging transnational university.
\end{abstract}

\section{RÉSUMÉ}

En prenant comme point de départ la fin de la guerre froide, le déclin le l'État-Nation, la mondialisation de l'économie et de la recherche, les transformations radicales apportées par les nouvelles technologies de la communication, et enfin les changement 
effectués par les gouvernements afin de trouver des ressources pour les corporations transnationales, cet essai examine le rôle des études littéraires et des sciences humaines dans le contexte des universités transnationales qui sont en train d'émerger...

The study[ 1 ] of English literature in the United States is in one major way like its study in Korea, Norway, Taiwan, Germany, or Italy. In another major way it is unlike. To study English literature in the United States, Korea, or Norway, to take it seriously as a source of values and humanistic understanding, is in all those cases to study the literature of a foreign country, a small and increasingly less important island nation off the west coast of Europe. The difference of course is that a version of English also happens to be the dominant, one might even say "official," language of the United States, whereas it is a second language in Korea, Norway, Taiwan, Germany, and the rest. The dominance of the American version of the English language in the United States, however, perhaps only makes it harder for us to see what is problematic about basing United States training in humanistic values on a literature that is not native to our soil. United States literature and English literature are by no means parts of one homogeneous whole, even though United States literature has traditionally been taught as subordinate part of English literature, as at my own university now and at the other two universities at which I have taught: Johns Hopkins and Yale. At Harvard, where I got my Ph.D., it was, in 1952 at least, not necessary to know anything at all about United States literature, any more than about Australian or Canadian literature, in order to get a Ph.D. in English. The difference between United States literature and English literature would have been more obvious all along if they had happened to have been written in different languages. Training in English literature is still the basis of literary education in the United States. At the University of California at Irvine, where I now teach, there are between six and seven hundred English majors. It is the only viable choice for undergraduates who want to concentrate on literature, even though almost half of the students at Irvine are Asian-Americans, many of whom have English as a second language. Chaucer, Shakespeare, Milton, Wordsworth, Dickens, Woolf - these still play a large role 
in determining the way citizens of the United States with a higher education think and behave.

These days, however, radical changes in society, in the university's relation to society, and in the study of literature are putting in question the traditional English major. By traditional English major I mean the more or less sequestered study of major canonical works by English authors from "Beowulf to Virginia Woolf," organized in courses devoted to historical "periods": Medieval literature, the Renaissance, the Eighteenth Century, Romanticism, the Victorian period, modernism, and postmodernism. Such a division makes many problematic assumptions about the canon, about the unity of works and periods, about the linear continuity of literary history, and so on. Just what changes are dismantling those assumptions, and just why have they occurred?

The Western research university in its modern form, as Bill Readings has shown, originated with the founding in the early nineteenth century of the University of Berlin. It was established according to the plan devised by Wilhelm von Humboldt. Such universities had as their primary role service to the nation-state, still nascent of course at that time in Germany. The nation-state was conceived as an organically unified culture with a single set of ideals and values enshrined in a unified philosophical tradition and national literature (or in a certain way of appropriating Greek and Latin literature). The university was to serve the nation-state in two ways: 1 ) as the place of critical thinking and research, finding out the truth about everything, giving everything its rationality, according to the Leibnizian formula that says nothing is without its reason; 2) as the place of education, formation, or Bildung where male citizens (they were all male then in the university) are inculcated, one might almost say "innoculated," with the basic values of a unified national culture. It was the business of the university to produce subjects of the state, in both senses of the word "subject": as subjectivities and as citizens accountable to state power and capable of promulgating it. For Humboldt and his colleagues, following Kant, the basis of Bildung was the study of philosophy. That is why those with a higher degree are still, for the most part, called "doctors of philosophy," whatever the discipline in which they received the degree. This is something of an absurdity these days, since philosophy proper does not, to say the least, still have the role it did in German universities in the days of Kant, Fichte, and Hegel, while most Ph.D.s in other fields know little or nothing about philosophy. 
With some support from Schiller's Letters on Aesthetic Education, Anglo-Saxon countries in the mid-nineteenth century, first England and then the United States, deflected this paradigm in an important way by substituting literature for philosophy as the center of cultural indoctrination. Grounds for this shift already existed in the centrality granted to literary education by many German theorists: the Schlegels, Schelling, and Hegel, for example. The shift occurred in England and in the United States to a considerable degree under the aegis of Matthew Arnold's formulations about culture and anarchy, about the study of poetry, and about the function of criticism. The modern United States research university has inherited the double mission of the Humboldtian university. This was evident in the founding of The Johns Hopkins University in Baltimore in 1876. The Hopkins was based explicitly and self-consciously on the German university rather than on the English university model, though Thomas Henry Huxley, as a spokesperson for the new scientific English university, spoke at the inauguration of Johns Hopkins. The admirable proliferation of both public and private research universities in the United States followed soon after or was already taking place.

The combination of gathering scientific knowledge (which includes knowledge of history, cultural history, and literary history, as well as knowledge of anthropolgy, physics, biology, and other social and physical sciences), while at the same time teaching a nation's unifying values, seems coherent enough. Nevertheless, a tension has always existed between these two goals as charges to the department responsible for doing research and teaching in a country's national literature. On the one hand, the charge is to teach students by way of literature the central ideas and values of a national culture. These are presumed to be enshrined in the nation's canonical works, in Beowulf, Chaucer, Shakespeare, and the rest in the case of English literature. On the other hand, scientific research is supposed to be critical and disinterested (Arnold's word), a search for truth independent of subjective bias. Research is value free, wertfrei. It is organized according to a universal methodology of verifiable research applicable mutatis mutandis to the human sciences as well as to the physical, social, and life sciences.

A touching confidence that these two enterprises would achieve the same results for a long time made it possible for those in departments of national literatures to believe they were fulfilling both missions and reconciling the two 
contradictory charges the university had given them. A professor of English could simultaneously pursue research of the most positivistic kind into the minutiae of an author's life, or do the most mind-numbing bibliographical or editorial work, and at the same time teach undergraduate classes extolling the ethical virtues contained in works by Milton, Johnson, Browning, Arnold and the rest. The first activity made him (they were almost all male) feel he was doing something useful to support his university's scientific devotion to truthseeking. He was adding to the archives of achieved knowledge. The second made him feel he was fulfilling his responsibility to Bildung. This combination was, for example, strongly institutionalized as the ethos of Johns Hopkins when I taught there in the 'fifties and 'sixties. We knew exactly what we were doing. Our assumptions seemed permanently in place, impossible to question.

The use of a foreign country's literature in the formation of United States citizens is a symptom of a fundamental change in the Humboldtian research university that took place when the model was adopted here. Bill Readings is right when he says that the concept of a unified national culture in the United States has always been a promise or hope for the future. It is something always yet to be created by contractual agreement among the free citizens of a republic rather than something inherited as an inescapable tradition from the nation's historical past. [ 2 ] It always remains up for grabs. English literature was co-opted by American schools and universities as the basic tool for the creation of a national culture that remains about to be, rather than something that is. Recent books have demonstrated that the creation of English literature as a pedagogical discipline occurred in the eighteenth and nineteenth centuries as part of British imperialism, whether in Scotland or in India. Franklin Court and Robert Crawford[ $\underline{\mathbf{3}}$ ] have shown how in Scotland English studies were devised as a way of putting down the Scots dialect and making Scotland more part of a unified Great Britain. Gauri Viswanathen[ $\underline{4}$ ] has shown how the study of English literature was used as an instrument of colonial domination in nineteenth-century India. The United States, however, did not need to be coerced into acting still like a colony, at least in the sense of taking its cultural ideals from English literature.

Some might argue that over the past fifty years United States citizens have come to recognize that they have an indigenous national literature that unifies them and make them all Americans. But the rise of so-called "American literature" and "American studies" as 
separate disciplines in universities and colleges demonstrates just the opposite. The important books on United States literature, from those by F. O. Matthiessen, Charles Feidelson, Jr., R. W. B. Lewis, and Perry Miller down to more recent work by Roy Harvey Pearce, Sacvan Bercovitch, and Harold Bloom, [ $\underline{\mathbf{5}}$ ] have been devoted not so much to describing as to attempting to create the unified national culture we do not have. They characteristically do this by a complex, performative, scholarly ritual that masks as objective scholarship. They appeal to such general concepts as the frontier ("Go west, young man"), the American renaissance, the American Adam, a certain use of symbolism, a certain use of romance, the Puritan ideal, the unity of a canonical poetic tradition from Emerson, Dickinson, and Whitman through Crane and Stevens to Ammons and Ashbery, and so on, in incoherent multiplicity. Different figurative paradigms for totalizing American literature appear and disappear like shadows in the mist. Each scholar makes up his or her own idea about the unity of American literature, and each idea is incompatible with the others. Readings says that the interest in canon formation in the United States arises from the fact that we do not have an inherited traditional canon and have tried to create one by fiat. This is another form of that future-anterior speech act characterizing United States culture generally. We project into the future what we need to have already in order to do the projecting. If one has a canon that can be taken for granted, as to a considerable degree the educated classes do in England, one does not need to worry about it or theorize about it. Only the somewhat maverick F. R. Leavis in England has in our time engaged in the sort of declarations about canon that in the United States are made by the scholars mentioned above.[ $\underline{\mathbf{6}}$ ]

All canon forming in the United States, however, is manifestly partial and invidious. An example is Bloom's central canon of American writers listed above. Not only are the chief authors in the canon all, with the exception of Dickinson, men and all from the North East. His canon also leaves out Thoreau, T. S. Eliot, W. C. Williams, Robert Lowell, Adrienne Rich, Sylvia Plath, Robert Frost, Theodore Roethke, and many others who from other perspectives would have a claim to be included in the canon of United States poets.[ 2 ] Any attempt to unify United States literature, however, will be biased and political, in short, ideological. I mean by "ideology" here the mistaking of a linguistic reality for a phenomenal one. Recent work, for example that by Carolyn Porter, calling for a disunified and multilingual American Studies, a discipline more reflective of the actual state of 
things, [ $\underline{\mathbf{8}}$ ] recognizes that these claims of unity were all along ideological, not real, or rather that they were performative, not constative. Their aim was to create by a speech act the unified culture we do not yet have. Such claims do this by appealing to a certain selective way of reading the past as though it were a tradition we all in the United States share in the way Germany, France, or England each has a unified national culture participated in by all its citizens. Or at any rate Germany, France, and England have thought they have a unified culture, while we are uneasily uncertain.

Of course the cultural oneness of Germany, France, or England was built on the exclusion of minority cultures, on the subordination of women, and on many other unjust acts of power. England achieved cultural unity through savage violence toward the Scots and Irish, through the suppression of Cornish, Gaelic, Scots, and Welsh languages, and so on. German cultural unity was to a considerable degree a fabrication of poets and philosophers: from Kant, Hegel, Fichte, Schiller, Goethe, the Schlegels, Hölderlin, and others on down to Heidegger and the poets of the Stefan George school. This German culture was built on two weird ideas, or ideas that any rate seem weird to anyone outside the German tradition. One was Fichte's assertion that anyone anywhere can think philosophically-as long as he or she does it in the German language, though of course not all Germans think philosophically.[ $\underline{\mathbf{9}}$ ] The other was the notion of a continuity between Greek and German culture, leaving Latin and Latinate or romance cultures out of the loop, so to speak, of cultural transmission. Both these strange but immensely productive notions are still fundamental in Martin Heidegger's thinking.[ 10 ] The importance of linguistic nationalism can hardly be overestimated in the power it has to determine national sentiment generally. It is as important as race or blood, as crucial as attachment to a single territory with sharp borders, the one-colored patch on the map. Even though nationalist sentiment in European countries has depended on extremely problematic and dangerous assumptions, and therefore has contained its own vulnerability within it, it has been even harder to sustain the idea of cultural unity in the United States.

The Humboldtian concept of literary study within the university lasted until quite recently, at least as an ideal, in the United States. It is now rapidly losing its force. We are entering an era in which new paradigms for the university will need to be found as well as new justifications for literary study. The changes are 
occurring simultaneously outside and inside the university.

On the outside, many forces are weakening the unity and borders of the nation-state. The end of the Cold War along with economic and technological globalization are more and more replacing separate nations with transnational corporations as centers of power. Bill Gates is perhaps more powerful than Bill Clinton. The European Common Market and the North American Free Trade Agreement are striking examples of the blurring of national borders and concurrent weakening of individual countries' self-determining autonomy. The development of an economic unity called "the Pacific Rim" is another example. The latter means that California belongs both to the United States and to an economic entity that includes companies in Japan, Korea, Taiwan, Singapore, Hong Kong, and will more and more include mainland China as well. These changes by no means make nationalist sentiment vanish. In fact they often exacerbate it. An example is England's resistance to having a common-market currency because it would mean giving up coins engraved with the queen's effigy. Other examples are the return to isolationist policies in the United States, nationalist wars in Eastern Europe after the collapse of the Soviet Union, similar civil wars in postcolonial Africa, and nationalist imperialism in Iraq or North Korea. Such forms of nationalism more and more appear hysterical and inappropriate to present economic realities. The way to prosperity is to learn English and to get as many international corporations as possible to set up factories in one's area and make capital investments there. As the nation-state's existence as a unified entity weakens through one form or another of globalization and the consequent eroding of national boundaries, it will be harder and harder to tell where France ends and Germany begins, even where the United States ends and Mexico begins. We shall all come to feel ourselves living on some margin, fringe, or borderland, at the periphery.

At the same time the integrity of the nation-state is weakening in another way. The United States is a striking example of that. In spite of energetic attempts by conservative politicians and educationists to impose a single language and a single literary curriculum, United States cultural life is made up of diverse interpentrating cultural communities speaking and writing in many different languages. These communities cannot easily be reconciled. Their sites are the loci of mutually incompatible goods. These values would be impossible to unify by some overarching idea of universal human 
"culture." Nor does any individual belong unequivocally to any one of these communities. In a few years more than half the citizens of California will have English as a second language. A poll taken recently of kindergarten classes in Irvine, California, an upper middle-class and homogeneous-looking city,[ 11 ] found that over twenty different languages were spoken in the homes of these children. They will grow up, like most Chicano/Chicanas, or like most Asian-Americans, divided within by participation in at least two incompatible cultures. The frequently used figure of "hybridity" to describe this situation is misleading. It implies that the hybrid individual participates in a mixed culture that is made by mating stable genes from the two sources. In fact the original cultures were by no means as stable or unified as an animal or plant species. In any case, the melting pot is no longer hot enough or capacious enough to melt all this difference down. Each self is inhabited by its other or by an indeterminate number of "others, " in plural swarming. No Habermasian dialogue, conversation, or communicative discourse could or should bring all this diversity back to consensus. The traditional single set of values transmitted by aesthetic education is now seen as what it always was: an ideological fabrication made to serve primarily the power of educated white middle or upper class heterosexual males.

What possible role can literary study have in the new technological transnational university? In the United States and in one degree or another in many other Western nations those responsible for funding higher education no longer believe that their nation needs the university in the same way as it once did. The primary evidence for this has been the cutting off of funds, almost always justified by budget constraints, as has been the case in the past few years for the University of California. That University was until recently arguably the greatest research university in the world. Now it has been weakened by budget cuts and through early retirements made for many professors irresistibly attractive by "golden handshake" offers of retirement benefits. About two thousand professors have taken early retirement. This procedure is borrowed from the corporate world. Those who pay for the university no longer have the same confidence in the need for basic research as something directly funded by the nation (that is, the Federal Government) or by its subdivisions, the separate states of the United States. Basic research was in any case always largely supported as ancillary to the military buildup. With the end of the Cold War came the end of the apparent need for many kinds of basic 
research. It is difficult for most humanities professors to accept the fact that their prosperity in the 1960s, 1970s, and 1980s was as much a result of the Cold War as was the prosperity of aircraft and weapons manufacturers, or as was the space race that put men on the moon.

Nevertheless, we were part of the military-industrial complex. The expensive development of humanities programs was an ancillary part of our need to be best at everything in order to defeat the Soviet Union in the cold war. This was made explicit in the legislation establishing the National Endowment for the Humanities. Now that the cold war is over, humanities programs are being "down-sized" along with scientific parts of university research and teaching. The NEH survives today with greatly reduced funding and is threatened with extinction. The job situation for newlytrained physicists is nearly as bad as it is for new Ph.D.s in English. For the latter it is extremely bad.[ 12 ] What those in charge (legislators, trustees, granting agencies, university adminstrators, foundation officers, and corporation executives) need, or think they need, and therefore demand, is immediately applicable technology. The weakening of our space program and the killing of the Superconducting Supercollider project are salient demonstrations of this. Much applied research can be done just as well or better by computer or pharmaceutical companies and the like. These have been increasingly funding applied research inside the university, coopting the university's scientific skills and laboratory facilities (often originally paid for by Federal money) for research that is oriented toward the discovery of patentable procedures that will make the companies rich. The university in response to these radical changes is becoming more and more like a bureaucratic corporation itself, for example by being run by a corps of proliferating administrators whose bottom line business, as is the case of any bureaucracy, is to perpetuate themselves efficiently, even if this sometimes means large-scale "administrative cutbacks."

The lack of a unified national culture in the United States has made it especially easy to shift with the global decline in the nation-state's importance to a university modelled on the bureaucratic corporation. The answer to the question, "Who now governs our universities," is that universities are more and more coming to be governed, however invisibly or indirectly, by corporations. This major change will have incaluculable effects on university teaching and research. Money is power, in this area as in others. As federal and state sources of funding are drastically reduced, both public and private universities are turning to corporations for funding. In 
the case of my own university, the University of California at Irvine, corporation support means seeking money from pharmaceutical companies, computer companies, medical technology companies, parts of the so-called "financial industry," media companies, and the like. These companies may be owned by Japanese, English, French, German, Korean, or Taiwanese corporations, or they may do much of their manufacturing or much of their sales outside the United States. In any case, they do not owe primary allegiance to a single nation-state. Moreover, they are not just any kind of corporations. They are companies that are participating in the world-wide transformation we call the coming of the information age or, more negatively, the age when everything is turned into spectacle. Today, money is information, passed around like other bytes on the Internet, just as information is money. An unbroken continuum binds pharmeceutical companies that deal in medical prostheses controlled by computer chips or that depend on genetic research to computer companies that invent the hardware and software making it possible to store and circulate information, for example in genetic research, to banking and investment companies that exchange the sort of information we call money, to media companies that turn everything into spectacle in film, television, and video, controlling thereby what people think, what they buy, and how they vote. These days an event does not "happen" unless it happens on television. The media formats determine what happens, even in the literal sense of transforming the way military "interventions" are conducted today, for example in Somalia and Bosnia.[ 13 ] The new global economy is not an economy in the old-fashioned sense of the production and distribution of goods. Theory's opponents lament the falsely-supposed suspension of language's referential function in so-called "deconstruction," but that suspension does actually characterize the new global economy in all its features. Giorgio Agamben, in a terrifying passage in The Coming Community, describes the way the new "society of spectacle" is transforming humankind everywhere and putting an end to the old securely founded and authorized nation-state:

In this extreme nullifying unveiling, however, language (the linguistic nature of humans) remains once again hidden and separated, and thus, one last time, in its unspoken power, it dooms humans to a historical era and a State: the era of the spectacle, or of accomplished nihilism. This is why today power founded on a presupposed foundation is tottering all over the globe and the kingdoms of the earth set 
course, one after another, for the democraticspectacular regime that constitutes the completion of the State-form. Even more than economic necessity and technological development, what drives the nations of the earth toward a single common destiny is the alienation from linguistic being, the uprooting of all peoples from their vital dwelling in language. . . Contemporary politics is this devastating experimentum linguae that all over the planet unhinges and empties traditions and beliefs, ideologies and religions, identities and communities.[ 14 ]

So what's the difference? As long as we get the funding can we not go on about our business of teaching and research in more or less the same old way? Do the faculty and the administration not still govern the university, determine its curricula and its research priorities? Are we not skilled in taking the money and doing more or less what we want with it? Have not humanists always benefitted from the affluence of scientific colleagues? To some degree the answer to all these questions is "Yes." Nevertheless, the shift from state and federal funding to transnational corporation funding is altering the research university and its governance more radically than many people yet recognize. Agamben does not mention the university, but it is easy to see that as the state loses its foundation so does the university that served the state. The university is transformed from being an educational state apparatus, in Althusser's term, or, more benignly, a place of critical and innovative thinking, into being one site among many others, perhaps an increasingly less important site, for the production and transfer of globally-exchanged information.

If the secrecy demanded by university military research during the cold war was deplorable, a new kind of secrecy is invading our universities, the secrecy demanded by corporations as a quid pro quo for their support of research. Two senior scientists in a department of biology, for example, each with his or her team of junior faculty, post-doctoral researchers, graduate students, and technicians, may each be funded by a different pharmeceutical company. Each scientist is accountable to the funding company. This means a subtle shift from basic research toward doing research that will result in marketable products, even though the companies probably tell the scientists to go on doing what they have been doing but to promise them first development rights if anything patentable happens to be 
discovered. It is also in the interest of the funding company to keep the results of research secret as long as possible, at least until the results are patented. This may delay the publication of research results, whereas research funded by the National Science Foundation or the National Instituites of Health has as a condition timely publication and universal access to the results of research. In the new situation two graduate students or two post-doctorals in the same department may be inhibited from discussing with one another or from using in teaching what they are are doing in their research work, in fundamental violation of basic assumptions about academic freedom. The measure of research accomplishment will be more and more not the acquisition of new knowledge but productivity as defined by the companies to whom the university is accountable. Almost the first thing the new President of the University of California, Richard C. Atkinson, did when he took office in the fall of 1995 was to hire consultants from the corporate world to advise him on how to make the central administration more "productive." It is easy to see that having applied the business-world model of productivity to his own bailiwick will justify later applying it also to the teaching and research activities that are the university's reason for being.

Individual professors in this new kind of university belong as much or more to international communities of those working in the same areas as they do to local research communities within their own universities. New communication technologies mean you can stay put in your own university and still be working on a research project with colleagues from many countries thousands of miles away. Another globalizing factor is the constant migration of professors and students from one country to another. This migration is a small-scale version of the unprecedented migration these days of large groups from one country to another, as work patterns change. In one academic year alone (1994-5) I had as colleagues working under my sponsorship scholars from Spain, Rumania, Bosnia, Japan, and Switzerland. Like many of my colleagues I lectured in many countries, in my case in England, Norway, Italy, the Netherlands, Denmark, Korea, Taiwan, and the People's Republic of China. I am uneasily aware that I have been doing my bit in these two ways to make my university part of a global organization detached from its local and national roots.

In a concomitant change, "society" (in the concrete form of legislators and corporations who give money to public universities and of trustees who manage and corporations who support private ones) also no longer 
needs the university to transmit national cultural values, however much such authorities may still pay lipservice to this traditional role of humanities departments. The work of ideological indoctrination and training in consumerism, it is tacitly understood, can be done much more effectively by the /21-22/ media, by newspapers and magazines, by television and cinema. Moreover, these academic bureaucrats and legislators are not stupid. After what has happened in humanities departments from the 1960s on, they now no longer trust professors of literature to do what they used to do or even, they might claim, what they are hired to do. The cat is out of the bag. Whatever the protestations of those running the universities about the eternal values embodied in the Western canon, the news has got through to them that the actual culture of the United States is multifarious and multilingual. Moreover, they know now that you can longer trust professors to teach Chaucer, Shakespeare, Milton, and the rest in the old ways. New ways of reading them have shown that these authors, read from a certain angle, as professors seem perversely inclined to do and to teach their students to do, are what some governing the university consider to be dynamite that might blow up the social edifice. So the more or less unconscious strategy is to welcome the selfdestruction of the traditional literature departments as they shift to cultural studies and then gradually cut off the money. In the case of public universities this is done in the name of financial stringency and the need to build more prisons and fund welfare programs. In the case of private universities the attempt to control what is taught in the humanities is sometimes more direct and blatant. An example is the \$twenty million gift to the humanities at Yale by Lee Bass, a member of a wealthy United States oil family. He thought his gift would entail the right to choose the professors his money would endow and the curriculum they would teach. What is most sinister about this dark episode, from which Yale admirably extricated itself by ultimately returning the gift, is the possibility that Mr. Bass's naiveté was not in assuming that his money would give him some right to govern the university but in being so upfront about it. Most such control is exercised in more tactful, subtle, and indirect ways. In a related change, professors have less and less importance as public affairs experts, no doubt because the media that allow those authorities to speak no longer have confidence that the ones from within the university will say what they want to hear, just as Lee Bass did not trust Yale to make appointments of which he would approve. The experts on Public Television panels, for example, are more and more 
drawn from conservatively funded think tanks rather than from universities.

Robert Atwell, president of the American Council on Education, recently asserted that American colleges and universities will be leaner and meaner by the year 2000: ". . . higher education is in its most dire financial condition since World War II."[ 15 ] This will happen not because universities want to be smaller and dumber, but because the money supply is being cut off. The articles discussing this bleak future recognize that many valuable programs are being eliminated. During the recession in the early 1990s faculty in the University of California were told that state funding would never rise again to the levels of the 1980s. This could not have been because the state would never again have enough money to return to those levels. California was already in 1995 out of its recession and becoming prosperous again, with surplus tax revenues. The annual state budget of the University of California is creeping back up to the level it had before the recession. This increase in funding must not, however, be misunderstood as a return to the prosperity of the 1980s. The increase is necessary to support salaries and student aid in the new down-sized university. Funding for individual divisions is still sharply down from historic levels.[ $\underline{\mathbf{1 6}}$ ] Less than one quarter of the total revenue of the University of California at Irvine in 1994-5 came from the State of California, whereas 52 percent was from state funding in 1984-5.[ 17 ] The assertion that funding will never rise to the old levels can have only one meaning. It means that the state of California, in the form of its governor and legislature, will not promise to give the old level of funding to the University of California even when the money becomes again available. They do not need the old university anymore enough to pay for it. They do not need its basic research in the same way. They do not even need the university for the primary stated purpose of giving a higher liberal education to all young citizens of California who have grade averages in high school above a certain level. The latter commitment was to some degree a cover for the real mission of the university, namely to do Cold War research.

The return of funding now is based on a new image of the university's mission: to aid the economic prosperity of the state of California as it becomes a big player on the global stage. It took those in charge only five years to figure out a new use for the university. This change is strikingly clear in recent statements by Pete Wilson, Governor of California, and Richard C. Atkinson, 
University of California President. In presenting his proposals for the California 1996-7 budget, Wilson said, "California universities and colleges have long been revered as the finest institutions in the world. Like the pioneers, entrepreneurs, and innovators who made California a land where any dream is possible, our institutions of higher learning are carrying on that tradition by preparing our students to compete and win in the global marketplace." Atkinson echoed Wilson almost word for word: "I applaud the governor's recognition of the important role higher education plays in preparing a skilled workforce for competition in the global marketplace and the important role UC plays in a healthy California economy."[ 18 ] What, one might ask, will be the role of literary study in this new university?

The Department of English and Comparative Literature at the University of California at Irvine where I teach is perhaps the strongest department in the whole university, as measured by the quality of those who apply to do graduate work, the scholarship of its faculty, its national ranking, and so on. Its reward for this accomplishment has been to lose seven of its senior faculty to the enticements of early retirement and to have its budget for graduate fellowships cut back to the point where much smaller numbers of graduate students can be accepted each year. It is difficult not to draw the conclusion that the State of California (in the form of voters, legislators, and university administrators) does not need what we have been doing enough to be willing to pay for it. Our position is weakened, I am bound to say, by the fact that it is not easy to justify the production of more and more Ph.D.s in English or Comparative Literature if there will be fewer and fewer jobs for them. My department is at present a strange mixture of a traditional English department, a large component of up-to-date American studies, a comparative literature program focusing on literary theory along with Renaissance and post-Enlightenment European literature, an internationally famous program in creative writing, a program in English composition, plus courses in women's studies, cultural studies, film studies, African-American studies, Native American studies, postcolonial studies, Chicano/Chicana Studies, and so on. It might be difficult to formulate the unifying rationale for all this or even the rationale for why it is disunified in just this way. We might be hard put to it to explain to someone, let us say a state legislator or a corporation CEO, what it is we do so well and why we ought to be doing just this and not some other thing, what good it is for the State of California and its citizens. 
What should we do in this new situation? First, we should take stock of these changes and try to understand them. Second, we must begin to think out ways to justify to our new constituency what we do in the humanities. This will not be at all easy, especially since corporation executives and officials have probably had their ideas about the humanities formed by the attacks in the media on theory, "political corrrectness," women's studies, and multiculturalism. We often start out with two strikes against us. Moreover, many of these funding sources as well as the university bureaucrats who govern for them may have a predisposition to think the humanities are primarily of use to teach "communication skills." In the new research university rapidly coming into being it will be extremely difficult to justify what we do in the old way, that is, as the production of new knowledge, the Wissenschaft appropriate in the humanities, as new knowledge about living things is appropriate in biology. New knowledge about Beowulf, Shakespeare, Racine, Hugo, or even Emerson, William Carlos Williams, and Toni Morrison is not useful in the same way new knowledge about genes is when it leads to the making of a marketable medicine. Those corporation officers who will more and more control the university are likely to say they admire the production of new knowledge in the humanities. Their general unwillingness to give money to support such research indicates that they do not really mean it.

The product of value we make in the humanities is discourse of a particular kind: new readings, new ideas. Nicholas Negroponte argues this forcefully for the research university in general in a recent essay in Wired[ 19 ]. Such ideas inaugurate something new, something unheard of before. Another way to put this is to say that the university is the place where what really counts is the ungoverned, the ungovernable. The ungovernable does not occur all that often. Most of what goes on in the university is all too easily governed. In fact it is self-governing, as when we say a machine has a "governor" that keeps it from running too fast. It just turns round at a moderate speed and keeps repeating the same. Nevertheless, the university has as its reason for being establishing conditions propitious to the creation of the ungovernable. Only if we can persuade the new corporate governors of the university that this has indispensable utility are we likely to flourish in the new conditions. Doing that will take much patient thought and rhetorical skill.[ $\underline{\mathbf{2 0}}$ ] 


\section{NOTES}

1. This essay is drawn from a book I am finishing entitled, "Black Holes: Literary Study in the Transnational University." The book is dedicated to the memory of Bill Readings, whose posthumous book, The University in Ruins (Cambridge: Harvard University Press, 1996), has greatly influenced my thinking about literary study in the university today.

2. As Readings puts this in a comment on Ronald A. T. Judy's (Dis) Forming the American Canon: African-Arabic Slave Narratives and the Vernacular (Minneapolis: University of Minnesota Press, 1993): "I am concerned to introduce a transitional step into the passage from the modern German University of national culture to the bureaucratic University of excellence, one which positions the American University as the University of a national culture that is contentless" (The University in Ruins, 201).

3. Franklin Court, Institutionalization of English Studies (Stanford: Stanford University Press, 1992); Robert Crawford, Devolving English Literature (Oxford: Clarendon Press, 1992). One chapter of Crawford's book is entitled, "The Scottish Invention of English Literature" (16-44).

4. Masks of Conquest: English Literature and Colonial Rule in India (New York: Columbia University Press, 1989).

5. F. O. Matthiessen, American Renaissance: Act and Expression in the Age of Emerson and Whitman (London, New York: Oxford University Press, 1941) ; Charles Feidelson, Symbolism and American Literature (Chicago: University of Chicago Press, 1953); R. W. B. Lewis, The American Adam ; Perry Miller, The New England Mind: From Colony to Province (Cambridge, Mass.: Harvard University Press, 1953); Roy Harvey Pearce, The Continuity of American Poetry (Princeton, N.J.: Princeton University Press, 1961); Sacvan Bercovitch, The Puritan origins of the American self (New Haven: Yale University Press, 1975); Harold Bloom, Figures of Capable Imagination (New York: Seabury Press, 1976).

6. See F. R. Leavis, The Great Tradition (Garden City, N.Y.: Doubleday, 1954). 
7. Bloom's The Western Canon: The Books and Schools of the Ages (New York: Harcourt Brace, 1994) is wider in scope and more ecumenical. I am speaking of Bloom's earlier essays on American authors, for example those in Figures of Capable Imagination. In an essay on "The Native Strain" in the latter, Bloom says: "There are a myriad of figures to illustrate American Orphism, but I want to confine myself here first to our very best poets (or those who seem best to me)-Whitman, Dickinson, a certain aspect of Stevens, and Hart Crane-and then to my own contemporaries I admire most, A. R. Ammons and John Ashbery" (75).

8. See Carolyn Porter, "What We Know that We Don't Know: Remapping American Literary Studies," American Literary History (Fall 1994), 6: 3: 469-526. Important work in this area includes: Paul Lauter, ed.

Reconstructing American Literature: Courses, Syllabi, Issues (New York: Feminist Press, 1983); A. LaVonne Brown Ruoff and Jerry W. Ward, eds., Redefining American Literary History (1990), Virginia YansMcLaughlin, ed., Immigration Reconsidered: History, Sociology, and Politics (New York: Oxford University Press, 1990), Donald Pease, ed., Revisionary Interventions into the Americanist Canon (Durham, $\mathrm{N}$. C.: Duke University Press, 1990), Philip Fisher, ed., The New American Studies (Berkeley: University of California Press, 1991), Gustavo Pérez Firmat, ed., Do the Americas Have a Common Literature? (Durham, N. C.: Duke University Press, 1990), Amy Kaplan and Donald Pease, eds., Cultures of United States Imperialism (Durham, N. C.: Duke University Press, 1993), Donald Pease, ed., National Identities and PostAmericanist Narratives (Durham, N. C.: Duke University Press, 1994), Paul Lauter, Canons and Contexts (New York: Oxford University Press, 1991), and the new Cambridge History of American Literature, eds. Sacvan Bercovitch and Cyrus Patell, of which two volumes of the eight planned have been published (Cambridge: Cambridge University Press, 1994, 1995). John Carlos Rowe helped me with this list. In the fall of 1996, Rowe will be convening a residential research group on PostNational American Studies at the Humanities Research Institute of the University of California. The goal is to work toward institutionalizing the new American studies in the University of California and other universities. See Alan Liu's forthcoming The Future Literary: Literary History and Postmodern Culture for a brilliant and fascinating discussion of the influence of computer technology and its graphic layouts on the presentation of new multicultural American literary histories or 
anthologies such as Heath Anthology of American Literature, Paul Lauter, gen.ed., 2nd ed. (Lexington, Mass.: D. C. Heath, 1994), and American Mosaic: Multicultural Readings in Context, compiled by Barbara Roche Rico and Sandra Mano (Boston: Houghton Mifflin, 1991). Paul Lauter's essay in the "Teacher's Manual" of the Heath Anthology is a good description of the changes now taking place in American literature and American studies.

9. This is a schematic summary of the complex argument made in the seventh of Fichte's Reden an die Deutsche Nation. See Johann Gottlieb Fichte, Reden an die Deutsche Nation (Berlin: In der Realschulbuchhandlung, 1808) and Addresses to the German Nation, ed. George Armstrong Kelley (New York: Harper and Row, 1968). For a discussion of Fichte's views see Jacques Derrida, "Privilège," Du droit à la philosophie (Paris: Galilée, 1990), 51-53, and "La main de Heidegger (Geschlect II)," Psyché (Paris: Galillé, 1987), 416-20.

10. See Jacques Derrida, De l'esprit: Heidegger et la question (Paris: Galilée, 1987), 112-6. For Heidegger, German is even better than Greek for speaking of the highest spritual things. As Derrida paraphrases this: "German is therefore the only language, in the final analysis, that can name that highest or superlative excellence (geistigste) which it does not share in the end except to a certain point with Greek" (113, my trans.). Philippe Lacoue-Labarthe's La fiction du politique (Paris: Christian Bourgois, 1987), English trans. by Chris Turner as Heidegger, Art and Politics: The Fiction of the Political (Oxford: Basil Blackwell, 1990), gives the best account of Heidegger's "national aestheticism," with its roots in German romanticism and its sinister links to the atrocities of National Socialism.

11. It is not really a city in the traditional sense: it has no center.

12. According Bettina J, Huber, in "The MLA's 1993-94 Survey of Ph.D. Placement: The Latest English Findings and Trends through Time," ADE Bulletin, no. 112 (Winter 1995), 48, only 45.9 percent of those who received a Ph.D. in English in 1993-94 got tenure-track jobs. See also Cary Nelson, "Lessons from the Job Wars: Late Capitalism Arrives on Campus," Social Text (Fall/Winter 1995), 13: 3: 119-134; Cary Nelson, "Lessons from the Job Wars: What is to Be Done," Academe (NovemberDecember 1995), 81: 6: 18-25. Two other essays from the same issue of Academe also discuss the current job market and the conditions of graduate study: Michael 
Bérubé, "Standard Deviation: Skyrocketing Job Requirements Inflame Political Tensions," 26-29, and Stephen Watt, "The Human Costs of Graduate Education; Or, The Need to Get Practical," 30-35. For the job outlook for new Ph.D.s in the physical sciences, see, in the same issue of Academe, Arthur S. Brill and Daniel J. Larson, "Are We Training Our Students for Real Jobs?," 36-38.

13. See Thomas Keenen, "Live from ... /En direct de ... ," Visite aux armées: Tourismes de guerre/Back to the Front: Tourisms of War (Caen: Fonds Régional d'Art Contemporain de Basse-Normandie, 1994), 130-63. "Comprehensive media coverage," says Keenen, "has not just changed the conduct of military operations-images and publicity have become military operations themselves, and the military outcome of the operation cannot easily be distinguished from the images of that operation" (143).

14. Giorgio Agamben, The Coming Community, trans. Michael Hardt (Minneapolis: University of Minnesota Press, 1993), 81-2.

15. Robert H. Atwell, "Financial Prospects for Higher Education," Policy Perspectives, The Pew Higher Education Research Program (Sept. 1992), 4:3: Sec. B, 5B.

16. The division of humanities at the University of California at Irvine, for example, suffered \$1,215,035 in budget cuts in the years 1992-95. No one seems to expect that support to return. A recent memorandum from the Dean of Humanities at Irvine quotes two recent statements by experts on American higher education in the 1990s. Donald Kennedy, former President of Stanford University, says: "It is inconceivable that our societal commitment to the support of knowledge acquisition will be maintained at historical levels. That circumstance alone signifies that university leaders are facing a period of resource restraint unlike any they-or their facultieshave ever experienced" ("Making Choices in the Research University,"Daedalus [Fall 1993], 130). David Breneman, an economist and specialist on higher education, declares that "Higher education is moving into a new era of permanently diminished financial support. ... The 'comprehensive college or university' may be an educational luxury that can no longer be supported in a meaningful way. . . . Having lost ground in the jockeying for state revenue, colleges and universities will find it hard to increase their share of appropriations. ... [California's] budgetary prospects continue to be 
bleak, particularly for higher education. . . . My conclusion is that higher education in California is in a state of emergency" (The first two sentences come from David Breneman, "Higher Education: On a Collision Course with New Realities," Association of Governing Boards of Universities and Colleges, AGB Occasional Paper No. 22, n.d. (but the paper was originally published in 1993 by American Student Assistance), 6, 13. The second two sentences are cited from David W. Breneman, "Sweeping, Painful Changes," The Chronicle of Higher Education, Section 2 [September 8, 1995]). The dean's response to this is to begin discussions of "Possible Academic and/or Administrative Reconfiguration of the School of Humanities." I think the reconfiguration is driven not just by the budget crisis but also by changing priorities resulting from a new definition of the university's mission. That mission will no longer be "knowledge acquisition" but service to the global economy. The study of European languages and literatures, for example, will have a much lower value in the new university, especially in one situated strategically on the Pacific Rim.

17. UCI News (January 24, 1996), 3.

18. Press releases of January 3, 1996.

19. Negroponte claims that research universities will have a crucial role in the new situation where companies rather than governmental agencies increasingly support universities. The companies will need the universities as the place where new ideas in all fields are developed. Quite correctly he sees that process as expensive in the sense that not all new ideas pan out, but, according to him, the pedagogical mission of the university (producing educated students) will carry that crucial innovative role along: ". . . companies have realized that they cannot afford to do basic research. What better place to outsource that research than to a qualified university and its mix of different people? This is a wakeup call to companies that have ignored universities-sometimes in their own backyards-as assets. Don't just look for 'well-managed' programs. Look for those populated with young people, preferably from different backgrounds, who love to spin off crazy ideas-of which only one or two out of a hundred may be winners. A university can afford such a ridiculous ratio of failure to success, since it has another more important product: its graduates" (Wired [January, 1996], 204). What Negroponte says is as true for the humanities as for the sciences, The challenge is to persuade those in charge of the value of new ideas in the humanities. 
20. This essay is drawn from a book I am finishing entitled, "Black Holes: Literary Study in the Transnational University." The book is dedicated to the memory of Bill Readings, whose posthumous book, The University in Ruins (Cambridge: Harvard University Press, 1996) has greatly influenced my thinking about literary study in the university today.

Accueil Surfaces | Table des matières | Recherche Surfaces Home Page | Table of Contents | Search

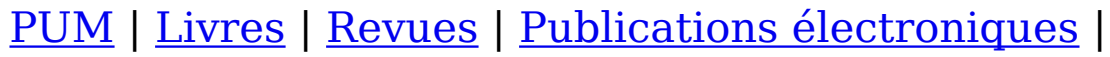
Vente et distribution 